\title{
Effect of RMI 12,936 on early pregnancy in mice
}

\author{
Geeta Parthasarathy and Safia R. Munshi \\ Institute for Research in Reproduction, Jehangir Merwanji Street, \\ Parel, Bombay 400 012, India
}

\begin{abstract}
Summary. Treatment with RMI 12,936 blocked the mitotic shift from epithelial to stromal cells normally observed in the uterus on Day 4 of pregnancy, and inhibited implantation. While progesterone alone could reverse the change in pattern of cell division in the preparation of the uterus for implantation, both oestradiol and progesterone were necessary to induce implantation and maintain pregnancy. A reduction in the activity of $\Delta^{5}-3 \beta$-hydroxysteroid dehydrogenase in the ovaries of RMI 12,936-treated mice suggests that the compound affects luteal synthesis of oestrogen and progesterone in mice.
\end{abstract}

\section{Introduction}

RMI 12,936 (17 $\beta$-hydroxy-7 $\alpha$-methyl-androst-5-en-3-one) has been reported to possess antifertility activity when administered at any time during gestation in rats (Kendle, 1975, 1976, 1978; Saksena, Salmonsen \& Lau, 1979b), hamsters (Lau \& Saksena, 1979) and rabbits (Saksena, Lau \& Chang, 1979a). In the rat, the compound caused an acceleration of egg transport and termination of pregnancy (Kendle, 1975), and was associated with a reduction in serum progesterone concentrations (Kendle, 1976) although no such reduction was found by Saksena et al. (1979b), who used a slightly different treatment schedule. However, Kendle \& Lee (1980) have now shown that administration of RMI 12,936 inhibits egg transport in the mouse through an antiprogestational effect. It is suggested that some metabolite of RMI 12,936 may be acting as a competitive antagonist for progesterone at the receptor level, inhibiting progesterone synthesis in the ovary (Taylor \& Kendle, 1978), or as an alternative substrate for $\Delta^{5}$-3ß-ketosteroid isomerase (Hardy, Kendle, Lawrie \& Omand, 1977). The present study was undertaken to determine whether RMI 12,936 plays any role in the preparation of the uterus for implantation and subsequent pregnancy in the mouse.

\section{Materials and Methods}

The mice, weighing $20-25 \mathrm{~g}$, were of the Swiss strain and of proven fertility. They were housed in air-conditioned rooms at a temperature of $21-24^{\circ} \mathrm{C}$, humidity of $55-60 \%$ and $14 \mathrm{~h}$ light $/ 24 \mathrm{~h}$. The animals were fed on standard laboratory diet and water was supplied ad libitum. The females were caged with fertile males on the afternoon of pro-oestrus. The day on which a vaginal plug was observed was considered as Day 1 of pregnancy.

RMI 12,936 was suspended in an aqueous vehicle containing $0.25 \%$ sodium carboxymethyl cellulose and $1 \%$ Tween 80 (Kendle, 1975). The mouse dose was extrapolated from the rat dose 
(Kendle, 1975), taking into consideration the surface area and body weight of the mouse. Progesterone and oestradiol were dissolved in olive oil.

Experiment 1. The effect of RMI 12,936 on mitotic cell division in the luminal, glandular and stromal cells of the mouse uterus was studied on Days 3 and 4 of pregnancy after arrest of mitosis by subcutaneous injection of $0.1 \mathrm{mg}$ colchicine in $0.1 \mathrm{ml}$ saline $(9 \mathrm{~g} \mathrm{NaCl} / \mathrm{l}) 1 \mathrm{~h}$ before autopsy. Mice were treated with $0.6 \mathrm{mg}$ RMI 12,936 on Days 1 or 2, on Days 1 and 2, or on Days 1, 2 and 3; some animals in the last group also received daily treatment with $1 \mathrm{mg}$ progesterone. The numbers of cells showing mitotic activity were counted in 20 serial sections of the uterine horns of each animal, and the mean \pm s.e.m. value was noted.

Experiment 2. On Day 4 of pregnancy, blastocysts were flushed from the uteri of mice treated with $0.6 \mathrm{mg}$ RMI 12,936 on Days 1,2 or 3 . Some animals were also treated with $1 \mathrm{mg}$ progesterone.

Experiment 3. Mice were injected with 0.3 or $0.6 \mathrm{mg}$ RMI 12,936 at $10: 00 \mathrm{~h}$ on Day 4 of pregnancy. To facilitate the detection of early implantation sites, $1 \%$ pontamine blue was injected intravenously before autopsy on Day 8 . The effects of simultaneous hormone treatments were investigated by injecting RMI 12,936-treated mice with $1 \mathrm{mg}$ progesterone daily from Days 4 to 20 or with $1 \mu \mathrm{g}$ oestradiol on Days 4 and 5 plus $1 \mathrm{mg}$ progesterone daily from Days 4 to 20 . The numbers of fetuses on Day 20 were recorded in other mice treated similarly.

Experiment 4. Animals were treated with 0.3 or $0.6 \mathrm{mg}$ RMI 12,936 on Day 4 of pregnancy and were autopsied on Days 6,7 or 8. Ovaries were weighed, frozen, and sectioned in a cryostat. They were histochemically stained for $\Delta^{s}-3 \beta$-hydroxysteroid dehydrogenase ( $\Delta^{s}-3 \beta$-HSD) by the method of Dickmann \& Day (1974), 17 $\beta$-hydroxysteroid dehydrogenase (17 $\beta$-HSD) by the method of Dey \& Dickmann (1974) and $\beta$-glucuronidase (EC 3.2.1.31) by the method of Fishmann \& Goldman (1965). Implantation sites were histochemically stained for alkaline phosphatase (EC 3.1.3.1) and acid phosphatase (EC 3.1.3.2) as described previously (Parthasarathy, Purandare, Katrak, Juneja \& Munshi, 1979). Leucine aminopeptidase (EC 3.5.1.4) was stained by the method of Nachlas, Crawford \& Seligman (1957). After staining the sections were mounted in glycerine jelly.

\section{Results}

Experiment 1. As shown in Table 1, the pattern of mitosis in mice in Groups $2-4$ and 6 and 7 did not differ from that observed for the respective vehicle-treated control (Groups 1 and 5).

Table 1. Effect of RMI $12,936(0.6 \mathrm{mg} / \mathrm{mouse} /$ day $)$ on uterine cell division in mice (6/group) on Days 3 and 4 of pregnancy

\begin{tabular}{|c|c|c|c|c|c|}
\hline \multirow[b]{3}{*}{ Group } & \multirow[b]{3}{*}{ Treatment } & \multirow[b]{3}{*}{ Day of autopsy } & \multicolumn{3}{|c|}{ Mean \pm s.e.m. no. of mitotic figures } \\
\hline & & & \multicolumn{2}{|c|}{ Epithelium } & \multirow[b]{2}{*}{ Stroma } \\
\hline & & & Luminal & Glandular & \\
\hline 1 & None & 3 & $10 \cdot 5 \pm 3 \cdot 8$ & $26 \cdot 33 \pm 4 \cdot 3$ & $1.0 \pm 0.4$ \\
\hline 2 & Day 1 & 3 & $8 \cdot 5 \pm 2 \cdot 6$ & $24 \cdot 21 \pm 3 \cdot 2$ & $1.2 \pm 0.6$ \\
\hline 3 & Day 2 & 3 & $8.0 \pm 2.4$ & $21.32 \pm 2.4$ & $1.4 \pm 0.8$ \\
\hline 4 & Day $1+$ Day 2 & 3 & $8 \cdot 3 \pm 1 \cdot 8$ & $23 \cdot 26 \pm 2 \cdot 8$ & $1.0 \pm 0.5$ \\
\hline 5 & None & 4 & $1.2 \pm 0.8$ & $1.6 \pm 0.5$ & $41 \cdot 6 \pm 4 \cdot 5$ \\
\hline 6 & Day 1 & 4 & $\overline{0}$ & 0 & $30 \cdot 2 \pm 3 \cdot 1$ \\
\hline 7 & Day $1+$ Day 2 & 4 & 0 & 0 & $32 \cdot 6 \pm 2 \cdot 3$ \\
\hline 8 & Day $1+$ Day $2+$ Day 3 & 4 & $9.4 \pm 1.2^{*}$ & $22 \cdot 26 \pm 4 \cdot 2^{*}$ & $1.2 \pm 0.1^{*}$ \\
\hline 9 & $\begin{array}{l}\text { Day } 1+\text { Day } 2+\text { Day } 3+ \\
\text { progesterone }\end{array}$ & 4 & $1.0 \pm 0.0$ & $1 \cdot 5 \pm 0.0$ & $40 \cdot 25 \pm 4 \cdot 1$ \\
\hline
\end{tabular}

* Significantly different from Group 5 vehicle control, $P<0.001$ (Student's $t$ test). 
However, RMI 12,936 administered on Days 1, 2 and 3 of pregnancy (Group 8) blocked the mitotic shift from epithelial to stromal cells observed on Day 4 of pregnancy. Simultaneous administration of progesterone (Group 9) overcame this inhibitory effect.

Experiment 2. Treatment with RMI 12,936 on Days 1, 2 and 3 of pregnancy reduced the number of blastocysts in the uteri on Day 4 (Table 2). Simultaneous progesterone treatment resulted in nearly normal blastocyst numbers.

Table 2. Effect of RMI $12,936(0.6 \mathrm{mg} /$ mouse $)$ on the mean \pm s.e.m. numbers of blastocysts in the uterus on Day 4

\begin{tabular}{lcc}
\hline \multicolumn{1}{c}{ Treatment } & No. of mice & $\begin{array}{c}\text { No. of } \\
\text { blastocysts }\end{array}$ \\
\hline None & 6 & $9 \cdot 2 \pm 0 \cdot 2$ \\
Day 1 & 6 & $5 \cdot 0 \pm 0 \cdot 2^{*}$ \\
Day 2 & 7 & $4 \cdot 0 \pm 0 \cdot 1^{*}$ \\
Day 3 & 7 & $1 \cdot 0 \pm 0 \cdot 1^{*}$ \\
Day 3+ progesterone & 6 & $8 \cdot 4 \pm 0 \cdot 2$ \\
\hline
\end{tabular}

* Significantly different from the value in the vehicle control group, $P<0.05$ (Student's $t$ test).

Experiment 3. Implantation was inhibited by treatment with RMI 12,936 on Day 4 of pregnancy (Table 3). Administration of progesterone alone had no effect but progesterone + oestradiol resulted in normal implantation and maintenance of pregnancy.

Table 3. Effect of RMI 12,936 and steroids on implantation in the mouse

\begin{tabular}{|c|c|c|c|c|}
\hline \multirow[b]{2}{*}{ RMI 12,936} & \multicolumn{2}{|c|}{ Treatment on Day 4} & \multicolumn{2}{|c|}{ No. of mice with: } \\
\hline & Progesterone & Oestradiol & $\begin{array}{c}\text { Implantation sites on } \\
\text { Day } 8\end{array}$ & $\begin{array}{l}\text { Fetuses on } \\
\text { Day } 20\end{array}$ \\
\hline - & - & - & $6 / 6$ & $6 / 6$ \\
\hline $0.3 \mathrm{mg}$ & - & - & $2 / 6$ & N.S. \\
\hline $0.6 \mathrm{mg}$ & - & - & $0 / 6$ & $0 / 6$ \\
\hline $0.6 \mathrm{mg}$ & $1 \mathrm{mg}^{*}$ & - & $0 / 6$ & $0 / 6$ \\
\hline $0.6 \mathrm{mg}$ & $1 \mathrm{mg}^{*}$ & $1 \mu g t$ & $6 / 6$ & $6 / 6$ \\
\hline
\end{tabular}

Experiment 4. Table 4 depicts the changes in the enzymes of ovaries and uteri of mice treated with RMI 12,936 on Day 4 of pregnancy. The activity of $\Delta^{5}-3 \beta$-HSD in the ovary and of alkaline phosphatase in the uterus decreased, but acid phosphatase and leucine aminopeptidase increased in activity. There was no effect on ovarian weights.

\section{Discussion}

During pregnancy, the change from epithelial to stromal mitosis occurs abruptly between Days 3 and 4, after exposure to progesterone for only 1 day (Finn \& Martin, 1967; Martin \& Finn, 1968). The uteri of mice treated with RMI 12,936 on Days 1,2 and 3 failed to reveal the 
Table 4. Effect of RMI 12,936 on mouse ovarian and uterine enzymest on Days 6-8 of pregnancy

\begin{tabular}{|c|c|c|c|c|c|c|c|}
\hline \multirow[b]{2}{*}{$\begin{array}{l}\text { Treatment } \\
\text { on Day } 4\end{array}$} & \multirow[b]{2}{*}{$\begin{array}{l}\text { No. of } \\
\text { mice }\end{array}$} & \multicolumn{3}{|c|}{ Ovary } & \multicolumn{3}{|c|}{ Uterus } \\
\hline & & $\Delta^{5}-3 \beta-H S D$ & $17 \beta-\mathrm{HSD}$ & $\begin{array}{l}\beta \text {-glucuroni- } \\
\text { dase }\end{array}$ & $\begin{array}{c}\text { Alkaline } \\
\text { phosphatase }\end{array}$ & $\begin{array}{c}\text { Acid } \\
\text { phosphatase }\end{array}$ & $\begin{array}{c}\text { Leucine } \\
\text { aminopeptidase }\end{array}$ \\
\hline Vehicle & 7 & $3 \cdot 0 \pm 0.1$ & $1.5 \pm 0.4$ & $1.8 \pm 0.2$ & $4.0 \pm 0.1$ & $2 \cdot 0 \pm 0.1$ & $2 \cdot 0 \pm 0.1$ \\
\hline $0.3 \mathrm{mg}$ & 8 & $2.7 \pm 0.2$ & $1.0 \pm 0.1$ & $1.3 \pm 0.2$ & $3.8 \pm 0.2$ & $2 \cdot 1 \pm 0.2$ & $2.2 \pm 0.1$ \\
\hline $0.6 \mathrm{mg}$ & 6 & $1.6 \pm 0.2^{*}$ & $1.0 \pm 0.1$ & $1.6 \pm 0.1$ & $1.4 \pm 0.2^{*}$ & $3 \cdot 0 \pm 0 \cdot 1^{*}$ & $3 \cdot 2 \pm 0 \cdot 1^{*}$ \\
\hline
\end{tabular}

Values are mean \pm s.e.m.

* Significantly different from the vehicle control value, $P<0.05$ (Student's $t$ test and Welch test).

$\dagger$ Estimated on a 4-point scale; $1 \cdot 0$, moderate; $2 \cdot 0$, good; $3 \cdot 0$, high; $4 \cdot 0$, intense.

cellular changes characteristic of Day 4 of pregnancy, but simultaneous administration of progesterone resulted in a normal appeárance of the uterus. Our earlier studies (Munshi, Purandare \& Rao, 1973) with LH antiserum treatment on Days 1, 2 and 3 also had the same effect which was completely reversed by progesterone alone. These results suggest that RMI 12,936 does not reduce endogenous oestrogen levels from Days 1 to 4 of pregnancy in mice, but it does interfere with the availability of progesterone from the corpus luteum.

Our results indicate that RMI 12,936 has an antifertility effect in mice by early expulsion of blastocysts from the uterus into the vagina. Simultaneous administration of $1 \mathrm{mg}$ progesterone was able to induce normal mitosis and restore normal numbers of blastocysts in the uteri on Day 4 of pregnancy in RMI 12,936-treated animals. These results agree with the data obtained by Kendle \& Lee (1980), indicating that progesterone activity is essential for the timely arrival of the blastocysts in the uterus on Day 4 of pregnancy in mice.

Our study also revealed that RMI 12,936 inhibits implantation in the mouse when administered during the preimplantation period. Characteristic morphological changes are evident at the time of implantation in the mouse (Munshi \& Parthasarathy, 1979). In mice injected with RMI 12,936 on Day 4 and autopsied on Day 6 of pregnancy, vascularization and stromal cell proliferation was not seen. The absence of these morphological changes indicates that implantation had not occurred because implantation was histochemically reflected by a decrease in alkaline phosphatase activity and increase in acid phosphatase and leucine aminopeptidase activities in the uterus on Days 6,7 and 8 of gestation. Continuous administration of progesterone alone was unable to overcome the inhibitory effect of RMI 12,936 on implantation, but oestradiol and progesterone were effective. Synthesis of progesterone and oestrogen in the ovary is dependent on the enzymic pathway which includes $\Delta^{3}-3 \beta$-HSD as one of the enzymes. Since the activity of this enzyme was decreased in the RMI 12,936treated mice, the compound may be antioestrogenic as well as antiprogestational at higher doses during implantation. A requirement for oestrogen on Days 6-8 (Exp. 3) confirms this view.

We thank Dr William L. Albrecht, Merrel Research Laboratories, Cincinnati, Ohio, U.S.A., for supplying RMI 12,936; and the Wyeth Laboratories and Ciba-Geigy Research Center, Bombay, for progesterone and oestradiol. The Pearse Slee Cryostat and chemicals used in the study were obtained through funds to the W.H.O., CCCR, Bombay.

\section{References}

Dey, S.K. \& Dickmann, Z. (1974) Estradiol-17ßhydroxy steroid dehydrogenase activity in preimplantation rat embryos. Steroids 24, 57-62.

Dickmann, Z. \& Dey, S.K. (1974) Steroidogenesis in the preimplantation rat embryo and its possible influence in morula blastocyst transformation and implantation. J. Reprod. Fert. 37, 91-93.

Finn, C.A. \& Martin, L. (1967) Pattern of cell division in the mouse uterus during early pregnancy. J. Endocr. 39, 593-597. 
Fishmann, W.H. \& Goldman, S.S. (1965) A postcoupling technique for $\beta$-glucuronidase employing the substrate naphthol As-B1- $\beta$-D-glucosiduronic acid. J. Histochem. Cytochem. 13, 441-447.

Hardy, D.G., Kendle, K.E., Lawrie, M.R. \& Omand, H.E. (1977) The effect of RMI 12,936, a synthetic antiprogestational steroid, on ovarian steroidogenesis in the rat. $J$. Reprod. Fert. 49, 231-235.

Kendle, K.E. (1975) Some biological properties of RMI 12,936, a new synthetic antiprogestational steroid. J. Reprod. Fert. 43, 505-513.

Kendle, K.E. (1976) Effect of RMI 12,936, a synthetic antiprogestational steroid in the rat. J. Reprod. Fert. 48, $159-166$.

Kendle, K.E. (1978) Further investigation of the antifertility effect in the rat of the antiprogestational steroid, RMI 12,936, and related compounds. $J$. Reprod. Fert. 52, 373-377.

Kendle, K.E. \& Lee, B. (1980) Investigation of the influence of progesterone on mouse embryo transport by using antiprogestational steroids. J. Reprod. Fert. 58, 253-258.

Lau, I.F. \& Saksena, S.K. (1979) Effect of RMI 12,936 on some reproductive processes in the female golden hamster. Contraception 19, 223-231.

Martin, L. \& Finn, C. A. (1968) Hormonal regulation of cell division in epithelial and connective tissues of the mouse uterus. J. Endocr. 41, 363-371.

Munshi, S.R. \& Parthasarathy, G. (1979) Endometrial enzyme activity associated with disruption of pregnancy in mice. In Recent Advances in
Reproduction and Regulation of Fertility, pp. 367-374. Ed. G. P. Talwar. Elsevier/North Holland, Amsterdam.

Munshi, S.R., Purandare, T.V. \& Rao, S.S. (1973) Effect of antiserum to ovine luteinizing hormone on uterine cell division during early pregnancy in mice. $J$. Endocr. 58, 123-124.

Nachlas, M.M., Crawford, D.T. \& Seligman, A.M. (1957) The histochemical demonstration of leucine amino peptidase. J. Histochem. Cytochem. 5, 264278.

Parthasarathy, G., Purandare, T.V., Katrak, B.J., Juneja, H.S. \& Munshi, S.R. (1979) Changes in uterine phosphatase levels in mice deprived of $\mathrm{LH}$ during early pregnancy. J. Reprod. Fert. 56, 297300.

Saksena, S.K., Lau, I.F. \& Chang, M.C. (1979a) Effect of $17 \beta$-hydroxy- $7 \alpha$-methyl-androst-5-en-3-one (RMI $12,936)$ in pregnant rabbits. Contraception 20 , 607-617.

Saksena, S.K., Salmonsen, R. \& Lau, I.F. (1979b) Termination of pregnancy in the rat by RMI 12,936 . Contraception 19, 481-488.

Taylor, R.B. \& Kendle, K.E. (1978) Use of HPLC to determine the effect of $17 \beta$-hydroxy-7 $\alpha$-methylandrost-5-en-3-one (RMI 12,936) on production of progesterone by rat ovarian homogenate. Acta endocr., Copenh. 88, 157-163.

Received 9 October 1980 